\title{
PENANGANAN REHABILITASI ORANG DENGAN GANGGUAN JIWA DI PANTI RENCENG MOSE, MANGGARAI, NUSA TENGGARA TIMUR
}

\author{
Isabela Dibyacitta Adelian, Ida Bagus Gde Pujaastawa, I Gusti Putu Sudiarna \\ Universitas Udayana (UNUD) Bali, Indonesia \\ Email: isabelaadelian@gmail.com,guspuja@gmail.com,igpsudiarna@yahoo.co.id
}

\begin{abstract}
Abstrak
Di Mangggarai, Nusa Tenggara Timur masih sering dijumpai fenomena Orang Dengan Gangguan Jiwa (ODGJ) yang kurang mendapat perhatian dari keluarga. ODGJ berkeliaran di jalanan dan menjadi bahan ejekan. Bahkan, keluarga cenderung menganggap ODGJ sebagai aib yang memalukan, sehingga menyebabkan terjadinya kesalahan dalam penanganan terhadap ODGJ, yakni pemasungan. Upaya penanganan ODGJ dapat dilakukan melalui rehabilitasi dengan tujuan untuk mempersiapkan dan memampukan ODGJ hidup mandiri di masyarakat. Di Manggarai, Renceng Mose merupakan tempat rehabilitasi bagi ODGJ. Penelitian ini bertujuan untuk menjelaskan fenomena rehabilitasi ODGJ dan implikasinya terhadap ODGJ serta keluarganya. Penelitian yang bersifat kualitatif ini membahas tentang persepsi orang Manggarai terhadap etiologi gangguan jiwa, faktor yang mempengaruhi proses dan mekanisme pengambilan keputusan sistem perawatan kesehatan ODGJ, dan implikasi penanganan rehabilitasi terhadap ODGJ dan keluarganya. Hasil penelitian ini menunjukkan bahwa penanganan rehabilitasi mampu mengembalikan ODGJ pada peran normalnya di masyarakat. Namun, stigma terhadap ODGJ dan keluarganya masih tetap ada, sehingga dapat menyebabkan ODGJ yang telah sembuh menjadi kambuh.
\end{abstract}

Kata kunci: rehabilitasi; ODGJ; keluarga

\section{Abstract}

In Manggarai, East Nusa Tenggara, the phenomenon of the people with mental disorders is still often encountered who received less attention from their families. People with mental disorders roam the streets and become the object of ridicule. In fact, families tend to regard people with mental disorders as an embarrassing disgrace, causing errors in handling of people with mental disorders. Efforts to handle people with mental disorders can be carry out through rehabilitation with the aim of preparing and enabling people with mental disorders to live independently in the community. In Manggarai, Renceng Mose is one of the rehabilitation center for people with mental disorder. This study aim to explain the phenomenon of the people with mental disorders rehabilitation and its implication for people with mental disorders and their families. This qualitative research discusses the Manggarai people's perception of the etiology of the mental disorders, factors that influence the decision-making process and mechanisms of the health care system of people with mental disorders, and implications of handling rehabilitation for people with mental disorders and their families. The result of this study indicate that rehabilitation treatment is able to restore people

$\begin{array}{ll}\text { How to cite: } & \text { Adelian, Isabela Dibyacitta, Ida Bagus Gde Pujaastawa, I Gusti Putu Sudiarna (2021) Penanganan } \\ & \text { Rehabilitasi Orang dengan Gangguan Jiwa Di Panti Renceng Mose, Manggarai, Nusa Tenggara } \\ & \text { Timur, Syntax Idea, 3(7). https://doi.org/10.36418/syntax-idea.v3i7.1373 } \\ \text { E-ISSN: } & \text { 2684-883X } \\ \text { Published by: } & \text { Ridwan Institute }\end{array}$


with mental disorders to their normal role in society. However, the stigma against people with mental disorders and their families still exist, so it can cause people with mental disorders who have recovered to relapse.

Keywords: rehabilitation; people with mental disorders; families

\section{Pendahuluan}

Masalah kesehatan mental merupakan salah satu dari sekian banyaknya permasalahan hidup yang dialami oleh manusia. Salah satu masalah kesehatan mental yang sering dialami manusia adalah gangguan jiwa. Berdasarkan data World Health Organization (WHO) pada tahun 2017 menunjukkan bahwa perkiraan penderita ganguan jiwa di dunia sekitar 450 juta jiwa. Di Indonesia berdasarkkan data (Riskesdas, 2018) terdapat sekitar 26 juta jiwa yang mengidap gangguan jiwa dan 13,2 juta di antaranya mengalami depresi.

Berdasarkan sejarah kesehatan mental (Siswanto, 2007) menyimpulkan bahwa terdapat berbagai pandangan yang ada di masyarakat mengenai sakit mental/sakit jiwa/gangguan mental. Adapun pandangan-pandangan tersebut, yaitu gangguan mental dipahami sebagai kerasukan roh; gangguan mental juga pernah dimaknai sebagai tindakan kriminal, seperti yang pernah dipahami oleh masyarakat Inggris; gangguan mental pernah dimaknai sebagai ketidakmampuan untuk berpikir rasional; dunia medis memandang penderita gangguan mental sebagai betul-betul mengalami sakit; ilmu perilaku memandang gangguan mental sebagai ketidakmampuan untuk melakukan penyesuaian diri dengan realita.

Menurut (Foster dan Anderson, 2015) menyatakan bahwa merupakan suatu keharusan bagi manusia untuk senantiasa menaruh perhatian terhadap masalah-masalah kesehatan serta untuk mempertahankan kelangsungan hidup. Manusia juga berusaha sejauh batas pengetahuannya untuk mencari penyelesaian terhadap masalah-masalah penyakit tersebut. Hal tersebut dilakukan sebagai bentuk adaptif yang didasari oleh logika dan rasa kasih. Berdasarkan (Undang-Undang Nomor 18 Tahun 2014 tentang Kesehatan Jiwa) upaya rehabilitatif kesehatan jiwa merupakan serangkaian kegiatan pelayanan kesehatan jiwa yang ditujukan untuk mencegah atau mengendalikan disabilitas, memulihkan fungsi sosial, memulihkan fungsi okupasional, mempersiapkan dan memberi kemampuan Orang Dengan Gangguan Jiwa (ODGJ) agar mandiri di masyarakat.

Panti Renceng Mose merupakan salah satu tempat rehabilitasi ODGJ yang terdapat di Manggarai, Provinsi Nusa Tenggara Timur (NTT). Orang Manggarai sering kali memperlakukan penderita gangguan jiwa sebagai bahan ejekan terutama yang bukan merupakan anggota keluarga penderita gangguan jiwa tersebut. Ketika melihat penderita gangguan jiwa sering kali diejek sebutan "ata wedol (orang gila)". Penderita gangguan jiwa di Manggarai seringkali tidak diperhatikan oleh keluarganya. Di jalanan ataupun di pusat kota tidak jarang ditemukan adanya ODGJ yang berkeliaran dengan kondisi fisik yang tidak terurus dan mengenakan pakaian kumal. Pada tingkat yang lebih parah, terdapat ODGJ yang sudah tidak mengenal keluarga maupun daerah 
asalnya. Selain itu, di Manggarai masih banyak ditemukan keluarga yang masih melakukan pemasungan terhadap ODGJ. Atas dasar pertimbangan tersebut penelitian ini penting untuk dilakukan serta dibahas dan dikaji secara ilmiah.

Menurut (Danandjaja, 1994) mengemukakan bahwa setiap kebudayaan memiliki aneka ragam tipe temperamen yang ditentukan oleh faktor keturunan (genetik) dan faktor ketubuhan (konstitusi) yang timbul berulang-ulang secara universal. Namun, setiap kebudayaan hanya memperbolehkan sejumlah terbatas dari tipe temperamen yang berkembang. Tipe-tipe temperamen tersebut hanya yang cocok dengan konfigurasi dominan. Mayoritas masyarakat akan berbuat sesuai dengan tipe dominan yang ada. Hal ini disebut dengan tipe kepribadian normal. Di sisi lain, terdapat sejumlah anggota masyarakat yang merupakan minoritas dan tidak dapat dimasukkan ke dalam tipe dominan. Ini disebabkan karena tipe temperamen tersebut terlalu menyimpang (deviate) dari tipe dominan (ruling type) atau tidak cukup berbakat untuk menyesuaikan diri dengan tipe dominan. Adapun Orang Dengan Gangguan Jiwa (ODGJ) adalah orang yang mengalami gangguan dalam pikiran, perilaku, dan perasaan yang termanifestasi dalam bentuk sekumpulan gejala dan/atau perubahan perilaku yang bermakna, serta dapat menimbulkan penderitaan dan hambatan dalam menjalankan fungsi sebagai manusia. Upaya rehabilitatif terhadap ODGJ meliputi rehabilitasi psikitiarik atau psikososial dan rehabilitasi sosial (Undang-Undang Nomor 18 tahun 2014).

Explanatory Model (EM) yang dicetuskan oleh Kleinman merupakan unsur penting dari suatu keputusan dalam rangka pemilihan sektor-sektor perawatan kesehatan yang akan digunakan. Hal ini penting karena EM merupakan suatu konsep atau petapeta kognitif yang senantiasa diacu dan digunakan oleh individu-individu, baik anggota masyarakat atau praktisi medis untuk menjelaskan kausalitas kejadian sakit, diagnosis, dan pengobatannya. Atas dasar EM ini masyarakat mengklasifikasi jenis-jenis penyakit mana yang dapat atau seharusnya ditangani oleh dokter atau rumah sakit dan jenis penyakit yang harus dibawa ke dukun yang tahu dan mampu mengobatinya (Kleinman, 1980). Berdasarkan teori Health Belief Model (Model Kepercayaan Kesehatan) yang dikembangkan oleh Rossenstock menekankan bahwa perilaku individu dalam masyarakat ditentukan oleh motif dan kepercayaannya tanpa memedulikan apakah motif dan kepercayaan tersebut sesuai atau tidak dengan realitas atau dengan pandangan orang lain terkait dengan apa yang baik untuk individu tersebut. Dalam hal ini sangat penting dibedakan antara kebutuhan dasar kesehatan yang objektif dan subjektif. Kebutuhan kesehatan yang objektif diidentifikasi oleh petugas kesehatan berdasarkan penilaiannya secara profesional, yaitu dengan adanya gejala yang dapat mengganggu atau membahayakan kesehatan individu. Sebaliknya, secara subjektif berarti individu menentukan sendiri apakah dirinya menderita penyakit berdasarkan perasaan dan penilaian sendiri. Pendapat atau kepercayaan ini dapat sesuai dengan realitas, tetapi dapat pula berbeda dengan realitas. Pendapat subjektif merupakan kunci dilakukannya atau dihindarinya suatu tindakan kesehatan. Artinya, individu itu akan melakukan suatu tindakan untuk penyembuhan penyakitnya jika dia benar-benar merasa terancam oleh 
penyakit tersebut. Sebaliknya, jika tidak merasa terancam, maka tidak akan melakukan tindakan apa-apa (Sarwono, 1993).

Menurut (Putro, 2019), stigma terhadap ODGJ berasal dari masyarakat, penderita, serta keluarga ODGJ. Stigma menyebabkan masyarakat maupun pihak rumah sakit menganggap ODGJ sebagai yang menyimpang. Stigma juga menyebabkan ODGJ yang telah keluar dari rumah sakit jiwa sebagai bekas ODGJ tetap terlabelisasi sebagai musuh sosial yang harus dihindari. Menurut (Soemarjono, 1998) mengungkapkan bahwa dukungan keluarga penderita, lingungan sekitar, dan hubungan yang baik dengan penderita dapat mempermudah resosialisasi penderita gangguan jiwa. Menurut (Tjana, 2020), pasien dalam menjalani pengobatan dan perawatan selalu mengimbangi pengobatan tradisional dengan pengobatan modern. Hal ini untuk membantu kesembuhan pasien karena pengobatan tradisional belum cukup ampuh untuk mengatasi gangguan jiwa. Pada tahun 2017 Nasriati mengungkapkan stigma tingggi yang dirasakan oleh keluarga ODGJ berdampak pada peningkatan beban keluarga, meningkatnya stress, berpengaruh terhadap kualitas hidup serta depresi. Penelitian yang berjudul "Penanganan Rehabilitasi Orang Dengan Gangguan Jiwa di Panti Renceng Mose, Manggarai, Nusa Tenggara Timur" ini menemukan bahwa rehabilitasi tidak dapat membebaskan ODGJ dari adanya stigma serta keluarga ODGJ masih sering melakukan pasung terhadap ODGJ yang kambuh setelah direhabilittasi.

Penelitian ini menjawab pertanyaan tentang hal-hal sebagai berikut. Pertama, persepsi orang Manggarai terhadap etiologi gangguan jiwa. Persepsi tersebut meliputi aspek naturalistik dan psikososio budaya (mitos tentang gangguan jiwa dan aspek personalistik). Kedua, faktor yang mempengaruhi proses dan mekanisme pengambilan keputusan sistem perawatan kesehatan ODGJ. Faktor tersebut meliputi pengetahuan dan kepercayaan mengenai gangguan jiwa, pengalaman orang lain, biaya, persepsi tentang keberadaan fasilitas pelayanan kesehatan, dan keparahan penyakit. Ketiga, implikasi penanganan rehabilitasi terhadap ODGJ dan keluarganya, yaitu terdiri atas implikasi positif dan implikasi negatif. Adapun manfaat teoritis penelitian ini adalah memperkaya pengetahuan bagi pengembangan ilmu pengetahuan, khususnya antropologi kesehatan. Selain itu, penelitian ini dapat menginspirasi peneliti-peneliti lain dalam bidang kesehatan. Secara praktis, penelitian ini memberikan manfaat bagi para penyusun dan pelaksana kebijakan di bidang kesehatan, khususnya kesehatan jiwa. Selain itu, penelitian ini memberikan masukan atau wawasan berpikir bagi para petugas rehabilitasi ODGJ untuk lebih meningkatkan kinerja dalam pengembangan tugas pelayanan bagi penderita gangguan jiwa. Penelitian ini juga dapat memberikan kesadaran bagi masyarakat mengenai implikasi penanganan rehabilitasi terhadap ODGJ dan keluarganya.

\section{Metode Penelitian}

Penelitian ini dilakukan di Panti Renceng Mose, Manggarai, Nusa Tenggara Timur dengan menggunakan data kualitatif. Data kualitatif adalah data yang dikumpulkan melalui penelitian dengan metode pengumpulan sebanyak mungkin fakta 
detail secara mendalam mengenai suatu masalah atau gejala guna mendapat pengertian tentang sebanyak mungkin sifat masalah atau gejala itu. Data yang dihasilkan berupa data yang bersifat deskriptif dan naratif yang diperoleh melalui pengamatan langsung terhadap objek yang diteliti dan hasil wawancara yang dilakukan terhadap informan (Suyono, 1985). Sumber data penelitian ini adalah berupa data primer dan data sekunder. Data primer merupakan data yang diperoleh secara langsung dari informan. Sedangkan, data sekunder ialah data yang diperoleh melalui kepustakaan, hasil penelitian terdahulu maupun studi dokumen. Adapun informan dalam penelitian ini adalah Kepala Bagian Rehabilitasi Gangguan Jiwa Renceng Mose, Direktur Renceng Mose, para tenaga kerja Renceng Mose, keluarga ODGJ dan penderita gangguan jiwa yang sedang/pernah mendapat perawatan di Panti Renceng Mose serta orang (masyarakat) Manggarai. Menurut (Sugiyono, 2017) langkah-langkah dalam melakukan analisis data sebagai berikut. a. Pengumpulan data, yakni dilakukan dengan cara observasi, wawancara mendalam, dan dokumentasi atau gabungan ketiganya (triangulasi). b. Reduksi data, meliputi merangkum, memilih dan memilah hal-hal yang pokok, memfokuskan pada hal-hal yang penting serta mencari temanya. c. Penyajian data berupa teks yang bersifat naratif. d. Penarikan kesimpulan dan verifikasi.

\section{Hasil dan Pembahasan}

\section{Persepsi Orang Manggarai Terhadap Etiologi Gangguan Jiwa}

\section{a. Aspek Naturalistik}

Dalam aspek naturalistik, penyakit (illness) dijelaskan dengan istilahistilah sistemik yang bukan pribadi. Naturalistik merupakan aspek yang di atas segalanya mengakui adanya suatu model keseimbangan. Sehat terjadi karena unsur-unsur yang tetap dalam tubuh, seperti panas, dingin, cairan tubuh (humor atau dosha), yin dan yang, berada dalam keadaan seimbang menurut usia dan kondisi individu dengan lingkungan alamiah dan lingkungan sosialnya. Apabila keseimbangan ini terganggu, maka hasilnya adalah timbulnya penyakit (Foster dan Anderson, 2015). Badan dan jiwa memiliki hubungan yang sangat erat. Gangguan kesehatan fisik dapat memicu terjadinya gangguan pada kesehatan jiwa. Hal ini dijelaskan oleh direktur Renceng Mose dr. Marianus Ronald Susilo, M.M., MARS sebagai berikut. (Jumat, 5 Februari 2021):

“...Gangguan jiwa adalah murni gangguan neurotransmitter di otak. Adanya zat-zat kimia yang mempengaruhi seseorang bisa mengalami gangguan jiwa. Gangguan neurotransmitter menyebabkan gangguan perilaku dan gangguan kejiwaan. Beberapa diagnosa dari penyakit gangguan jiwa bukan murni dari gangguan neurotransmitter otak tetapi bisa juga dari pengaruh pendidikan keluarga, lingkungan sosial, ekonomi dan sebagainya. Faktor-faktor itu akan mempengaruhi hormonal dan zatzat kimia dalam tubuh sehingga menyebabkan gangguan jiwa”.

Otak manusia merupakan pusat pikir, pusat kesadaran, dan pusat emosi. Antara pikiran dan emosi terdapat jalinan yang sangat erat karena semuanya 
terjadi di otak. Emosi pada gilirannya akan mempengaruhi kerja sistem saraf, hormonal maupun fungsi otak lainnya. Orang yang cerdas secara emosi mampu mengintegrasikan kerja seluruh bagian otaknya sehingga mampu berfungsi secara optimal (Siswanto, 2007). LJ (eks ODGJ) menerangkan gejala gangguan jiwa yang pernah dialaminya sebagai berikut. (Senin, 8 Februari 2021):

"... Sebelumnya saya sering mengalami sakit kepala. Saya rasa kepala saya mau pecah dan meledak. Rasanya menusuk sekali. Di bagian tubuh yang lain saya tidak merasakan sakit. Hanya di kepala saja. Akhirnya, saat saya umur 24 tahun, saya sudah mulai menunjukkan gejala gangguan jiwa. Saya suka jalan-jalan sembarangan".

Dalam rangka memenuhi kebutuhan hidup cukup banyak ditemukan masyrakat Manggarai yang merantau ke luar provinsi maupun ke luar negeri. Hal ini dikarenakan kurangnya lapangan pekerjaan maupun upah pekerja yang rendah, sedangkan biaya hidupnya mahal. Setelah di perantauan beberapa di antaranya mengalami gangguan jiwa sehingga menyebabkan mereka dipulangkan ke Manggarai. Direktur Renceng Mose juga menambahkan bahwa tekanan untuk memenuhi kebutuhan hidup dapat memicu seseorang mengalami gangguan jiwa. (Suci, 2018) juga mengungkapkan bahwa semakin tinggi beban kerja, maka semakin meningkat stres kerja.

\section{b. Pandangan Gangguan Jiwa secara Psikososio Budaya}

\section{1) Mitos tentang Gangguan Jiwa}

Ditinjau dari teori konfigurasi budaya, ODGJ merupakan kelompok penyimpang yang tidak mampu untuk menyesuaikan diri dengann tipe temperamen dominan. Atas dasar hal tersebut, pasung dianggap sebagai tindakan yang pantas bagi ODGJ. Pasung adalah tindakan yang mengekang ODGJ dengan menggunakan peralatan, seperti rantai, belenggu, balok kayu, kurungan, diasingkan maupun dirantai pada ruangan terasing. Masyarakat Manggarai menganggap bahwa pemasungan terhadap ODGJ lebih efektif karena tidak mengganggu atau membahayakan orang lain dan bisa diawasi pergerakkannya. Berikut ini contoh fenomena pasung di Manggarai berdasarkan catatan perjalanan Bruder Honorius. (Senin, 8 Februari 2021):

“...Sejak tahun 2015 dia mulai menunjukkan tanda-tanda gangguan jiwa. Dia kesulitan tidur, sulit merawat diri, selalu mengurung diri di dalam kamar, kadang marah tanpa sebab, dan kadang merusak barangbarang yang ada di sekitarnya. Karena merasa ketakutan dan terganggu dengan keadaannya, maka warga sekitar rumah menyuruh keluarganya untuk memasung dia. Awalnya keluarganya tidak tega, tapi kondisi ODGJ ini masih dan semakin mengkhawatirkan. Oleh karena itu, keluarga buat sebuah bangunan kecil di belakang dapur sebagai tempat tinggal ODGJ ini tadi. Dia dikurung di bangunan kecil itu, makan di situ, buang air kecil dan besar di situ serta berbagai aktifitas lainnya”. 
Stigma menjadi suatu bumerang yang seringkali dialami oleh ODGJ. Menurut (Herdiyanto, 2017) pengetahuan terkait dengan kesehatan jiwa menjadi faktor yang mneyebabkan munculnya stigma terhadap ODGJ dan anggota keluarganya. Stigma terhadap ODGJ dapat memperburuk atau memperparah kondisi ODGJ. Dampak stigma dijelaskan oleh L (keluarga eks ODGJ) melalui pernyataan di bawah ini. (Kamis, 11 Februari 2021):

“...Waktu pulang dari Kalimantan sebenarnya dia sudah sembuh. Suatu hari waktu duduk di pangkalan ojek ada yang ejek dia, bilang bahwa dia gila. Setelah kejadian tersebut dia sangat malu dan selama satu minggu selalu mengurung diri di kamar. Ketika ditanyai dia hanya mengatakan bahwa dia baik-baik saja. Kami bingung kenapa dia begitu. Tapi, untungnya ada yang cerita ke kami kalau dia diejek waktu di pangkalan ojek. Setelah kejadian itu, gejala gangguan jiwanya muncul lagi dan sampai pada akhirnya kami putuskan untuk bawa dia ke Renceng Mose".

\section{2) Aspek Personalistik}

Suatu sistem personalistik adalah suatu sistem dimana penyakit (illness) disebabkan oleh intervensi dari suatu agen yang aktif, yang dapat berupa makhluk supranatural (makhluk gaib atau dewa), makhluk yang bukan manusia (seperti hantu, roh leluhur, atau roh jahat) maupun makhluk manusia (tukang sihir atau tukang tenung). Orang yang sakit adalah korbannya, objek dari agresi atau hukuman yang ditujukan khusus kepadanya untuk alasanalasan yang khusus menyangkut dirinya saja (Foster dan Anderson, 2015). Pandangan ini masih sangat relevan di kehidupan masyarakat Manggarai. Masyarakat Manggarai mengakui bahwa sakit bukan hanya disebabkan oleh hal-hal yang terlihat, tetapi juga disebabkan oleh hal-hal yang tidak terlihat. Masyarakat Manggarai masih meyakini bahwa gangguan jiwa disebabkan oleh kerasukan setan atau roh jahat. Menurut (Simanjuntak, 2013) menjelaskan bahwa kerasukan setan merupakan peristiwa hadirnya roh jahat dalam kehidupan manusia dan dipercaya dapat menyebabkan kepribadian seseorang berubah. Pribadinya menjadi tidak sesuai dengan situasi dan lingkungan sosialnya. Kerasukan setan juga dipercaya sebagai suatu peristiwa yang membuat orang sakit secara fisik dan mental. Berikut adalah penjelasan MS (62 tahun) mengenai kerasukan roh. (Senin, 1 Maret 2021):

“...Biasanya kita sering minta petunjuk ke roh orang mati. Roh orang mati bisa kita panggil dan bawa ke alamnya kita. Orang yang bisa panggil mereka ata mbeko (dukun) ataupun siapa saja yang punya kemampuan untuk panggil mereka. Saat buat ritual pemanggilan roh biasanya harus lewat perantara. Maksud saya, manusia yang masih hidup. Siapapun orangnya boleh jadi perantara. Orang yang bisa panggil roh harus bisa juga untuk keluarkan roh orang mati dari tubuh manusia yang hidup tadi. Yang berbahayanya itu kalau orang yang panggil roh ini tidak bisa keluarkan roh orang mati dari tubuh manusia 
yang hidup tadi. Dampak buruknya nanti roh orang mati ini akan jadi penguasa di tubuhnya manusia kalau yang jadi perantara ini tidak kuat secara fisik dan jiwanya. Ini yang buat manusia yang jadi perantara tadi bisa jadi gila. Dan kalau yang sudah parah bisa saja dia mati. Kerasukan setan atau roh jahat itu bisa saja karena kita sering melamun atau kosong pikiran. Ada juga kasus orang kerasukan setan karena dia disukai setan".

(Herdiyanti dan Cholilah, 2017) mengungkapkan bahwa upacara adat merupakan salah satu bentuk identitas budaya lokal. Upacara adat sebagai manifestasi rutual adat yang sangat penting bagi masyarakat yang dilaksanakan dalam periode tertentu. Masyarakat Manggarai meyakini bahwa kesalahan dalam melakukan ritual adat dapat menyebabkan seseorang mengalami gangguan jiwa. Hal ini didukung oleh pernyataan MP (63 tahun) berikut ini. (Minggu, 21 Februari 2021):

"...Dalam melakukan ritual adat apabila yang dilakukan tidak sesuai dengan ketentuan adat dapat membawa dampak buruk bagi pelaku adat tersebut. Akibatnya dapat langsung terjadi setelah ritual dilakukan ataupun bisa juga setelah dua atau tiga bulan melakukan ritual. Biasanya orang yang melakukan kesalahan tersebut pada tingkat yang parah akan mengalami kematian, bukan hanya gangguan jiwa saja. Gangguan jiwa yang disebabkan karena melanggar adat bisa menyebabkan dikucilkan dari keluarga dan lingkungan sosial”.

Masyarakat Manggarai juga menganggap penyakit gangguan jiwa sebagai suatu karma akibat suatu kesalahan leluhur atau nenek moyang mereka. Gangguan jiwa yang dialami oleh keturunannya menjadi tebusan atas kesalahan yang dibuat oleh para pendahulunya. Dengan hal itu, maka kesalahan masa lalu dapat diampuni atau dimaafkan. Berikut adalah penuturan FM (60 tahun). (Rabu, 24 Februari 2021):

“...Kalau kami renungkan tentang anak ini. Kami pikir mungkin dulu leluhur kami pernah buat dosa besar. Bisa jadi lewat anak yang sakit ini kami dapat karmanya. Kami harus tanggung penderitaan dan sengsara ini agar bisa terbebas dari karma buruk. Ada juga benda-benda warisan dari leluhur yang kami tidak tahu betul fungsinya. Selama ini bendabenda itu kami hanya simpan baik saja. Kami tidak pernah pakai karena tidak tahu fungsinya. Tetapi, setelah anak ini sakit, kami buang semua benda-benda ini. Jangan-jangan benda yang kami simpan itu ada pengaruh negatifnya. Sebelum dibuang kami minta berkat dari pastor dulu. Mungkin ini ada hubungannya dengan benda peninggalan leluhur yang kami miliki. Oleh karena itu semua benda peninggalan itu kami buang".

Pada banyak suku bangsa yang belum sepenuhnya menerima konsepsi ilmu kedokteran tentang penyakit, rupa-rupanya hiduplah konsepsi universal tentang sebab dari penyakit-penyakit itu. Konsepsi-konsepsi itu antara lain 
bahwa penyakit disebabkan karena jiwa menghilang keluar dari tubuh, tubuh dimasuki roh jahat, tubuh kena sinar "mata sakti", tubuh kemasukan suatu benda, tubuh kena pengaruh suatu perbuatan ilmu gaib agresif, tubuh dikotori hal-hal najis, orang melanggar suatu pantangan, atau larangan adat dan agama (Koentjaranigrat, 1992).

\section{Faktor yang Mempengaruhi Proses dan Mekanisme Pengambilan Keputusan Sitem Perawatan Kesehatan ODGJ}

Faktor yang mempengaruhi proses dan mekanisme pengambilan keputusan sistem perawatan kesehatan ODGJ tidak terlepas dari pandangan masyarakat atau individu dalam menginterpretasi sumber penyakit, mendiagnosa, dan mengobati suatu penyakit. Mengacu pada teori explanatory model, pengambilan keputusan sistem perawatan kesehatan ODGJ di Panti Renceng Mose dipengaruhi oleh pengetahuan dan kepercayaan mengenai gangguan jiwa, pengalaman orang lain, biaya, persepsi tentang keberadaan fasilitas pelayanan kesehatan serta keparahan penyakit. Penjabaran lebih lanjut mengenai hal tersebut akan dijelaskan sebagai berikut.

\section{a. Pengetahuan dan Kepercayaan Mengenai Gangguan Jiwa}

Masalah kesehatan mental bukan merupakan masalah fisik yang dengan mudah dapat diamati dan terlihat. Berbeda dengan gangguan fisik yang dapat dengan relatif mudah dideteksi, orang yang mengalami gangguan kesehatan mental sering kali tidak terdeteksi, sekalipun oleh anggota keluarganya sendiri. Hal ini lebih karena mereka sehari-hari hidup bersama sehingga tingkah lakutingkah laku yan g mengindikasikan gangguan mental dianggap hal yang biasa, bukan sebagai gangguan (Siswanto, 2007).

Mariana Suryani Jenia, seorang perawat Renceng Mose menjelaskan bahwa ada ODGJ yang dibawa ke Renceng Mose setelah bertahun-tahun mengalami gangguan jiwa dan ada juga yang baru beberapa minggu menunjukkan gejala langsung di bawa ke sini. Cepat dan tidaknya penanganan terhadap ODGJ sangat dipengaruhi oleh pengetahuan atau pemahaman keluarga mengenai gejala gangguan jiwa. Selain itu, Riyanto dan Budiman pada tahun 2013 mengungkapkan bahwa pengetahuan disimpan dalam wujud nyata dan dideskripsikan dalam tindakan-tindakan yang berhubungan dengan kesehatan. Masyarakat yang mmenganggap gangguan jiwa sebagai kerasukan setan berobat ke pendoa. Setelah tidak berhasil dengan pengobatan tradisional, mereka menyadari bahwa sesungguhnya yang dianggap sebagai kerasukan setan adalah gangguan jiwa. Hal ini didukung dengan pernyataan pernyataan A (eks ODGJ) berikut ini. (Senin, 15 Februari 2021)

“...Saya rasa ada sesuatu yang masuk ke tubuhnya saya. Semacam kerasukan begitu. Setiap kali lihat orang sepertinya ada bayangan hitam yang muncul. Dua hari setelah itu, mama ajak saya ke pendoa di La'o. Tapi, tidak sembuh. Tidak ada perubahannya. Akhirnya, mereka bawa saya ke Renceng Mose. Sebenarnya juga saya waktu itu terlalu banyak pikiran. Waktu itu kan saya baru saja selesai kuliah to. Saya tidak langsung kerja. 
Saya mau bersantai-santai di rumah dulu. Tetapi, ada yang bilang begini ke saya kalau percuma saja sekolah tinggi tetapi tidak kerja, malah jadi pengangguran. Saya tipe orang yang mudah kepikiran. Kalau ada orang yang omong jelek namanya saya, saya langsung kepikiran. Saya gampang kepikiran dan mudah sekali untuk tidak tenang karena omongannya orang. Karena itu saya jadinya lebih sering mengurung diri di kamar. Saya merasa malu, tidak percaya diri, dan minder kalau bertemu orang lain. Saya juga sering melamun".

Dari penuturan A (eks ODGJ) dapat dijelaskan bahwa ketika pertama kali menunjukkan gejala gangguan jiwa, keluarga ODGJ melakukan perawatan pertama kali ke dukun atau pendoa. Hal ini terjadi karena masih tingginya kepercayaan masyarakat Manggarai yang menganggap sakit secara personalistik. Secara personalistik masyarakat Manggarai masih menganggap gangguan jiwa sebagai kerasukan setan. Di sisi lain, hal ini juga menunjukkan bahwa pengetahuan keluarga tentang gangguan jiwa masih kurang. Padahal keluarga mempunyai tugas untuk membuat keputusan tindakan kesehatan yang tepat bagi anggota keluarga yang sakit. Walaupun demikian, setelah putus asa dengan pengobatan yang dilakukan oleh dukun, keluarga menyadari bahwa yang mereka anggap sebagai kerasukan setan adalah gangguan jiwa, yakni dipengaruhi oleh adanya beban pikiran.

Menurut (Kasniyah, 1985) menuturkan bahwa sistem-sistem medik tradisional pada kenyataanya masih tetap hidup, tidak terhapuskan oleh praktikpraktik biomedik kedokteran yang semakin mengalami perkembangan. Kenyataan inilah yang menunjukkan bahwa pelayanan dan perawatan kesehatan merupakan fenomena sosial budaya yang kompleks. Usaha penyembuhan penyakit yang dijalani penderita tidak hanya dilakukan di puskesmas, rumah sakit, dokter praktik umum, dan spesialis, tetapi dapat pula dilakukan secara tradisional. Hal ini didukung oleh pernyataan SL (keluarga pasien) di bawah ini.(Minggu, 14 Februari 2021):

"...Mengenai sakitnya mama saya mencari pengobatan secara tradisional dan perlu juga berobat ke tenaga medis. Percuma minum obat dari klinik atau dokter kalau pengaruh setannya tidak dikeluarkan atau dibuang karena setannya menghalangi atau menghambat kerja obat dari dokter. Itulah mengapa kedua pengobatan itu saya jalankan secara bersamaan. Tidak perlu dengar apa yang orang katakan selama apa yang dibuat bisa menyembuhkan mama."

Dari penuturan SL (keluarga pasien) di atas juga menunjukkan bahwa pengobatan tradisional dan modern saling mendukung atau melengkapi. Pengobatan tradisional melalui dukun dilakukan untuk menghilangkan pengaruh setan. Apabila pengaruh setan dalam diri ODGJ sudah hilang, maka pengobatan secara medis dapat dilakukan dengan baik. Keluarga tidak peduli dengan 
tanggapan negatif orang lain mengenai sistem perawatan kesehatan yang mereka pilih dan lakukan selama apa yang dilakukan adalah untuk kesembuhan ODGJ.

\section{b. Pengalaman Orang Lain}

Dalam memilih jenis pelayanan kesehatan, baik secara tradisional maupun medis, masyarakat sering kali memperhatikan sejauh mana jenis pelayanan tersebut bisa memberikan kesembuhan. Oleh karena itu, pengalaman orang lain dalam menjalani suatu perawatan kesehatan secara tradisional maupun medis menjadi sangat penting. Berikut ini adalah penjelasan MA (keluarga pasien) mengenai pengambilan keputusannya dalam melakukan perawatan terhadap salah satu orang tuanya yang mengalami gangguan jiwa. (Rabu, 3 Maret 2021):

“...Dulu mama pernah dirawat di panti rehabilitasi yang di Maumere. Tapi di sana mama tidak dirawat dengan baik. Akhirnya kami bawa pulang dan rawat sendiri. Karena kondisinya tidak membaik, mama besar saya yang di Jakarta minta dia dibawa ke Jakarta untuk dirawat di sana. Tapi, selama sepuluh bulan di sana juga tidak ada perubahan, kondisinya masih sama saja. Lalu, pulang lagi ke Flores dan rawat jalan. Tetap dapat obat dari dokter di Jakarta. Setelah beberapa tahun tidak ada perubahan, makanya kami langsung bawa ke Renceng Mose setelah dapat info. Saya bawa mama ke Renceng mose karena dengar dari ceritanya orang".

Hal serupa juga dijelaskan oleh SL (keluarga pasien) sebagai berikut. (Minggu, 14 Februari 2021):

“...Awalnya dulu kami bawa dia ke ata mbeko dan pendoa. Kami sudah banyak sekali ketemu dengan dukun ataupun pendoa yang ada di Manggarai ini dan mereka bilang kalau sakit yang dialami oleh ine (mama) karena orang yang buat. Kami bawa dia ke ata mbeko karena dengar cerita pengalamannya orang yang punya sakit seperti ine dan sembuh setelah berobat ke sana. Ine juga minum ramuan tradisional dari tanaman. Tetapi, selama bertahun-tahun kami berobat ke banyak sekali ata mbeko tidak ada satupun yang bisa sembuhkan ine. Suatu ketika saya ketemu Om Frans. Om Frans ini punya anak yang alami gangguan jiwa dan sudah pernah direhabilitasi di Renceng Mose. Dia ceritakan banyak hal tentang bagaimana pengalaman anaknya dirawat di Renceng Mose. Dengar ceritanya Om Frans kami sekeluarga akhirnya putuskan untuk rawat ine di Renceng Mose."

Berdasarkan penuturan di atas dapat dijelaskan bahwa pengalaman dari orang yang pernah melakukan perawatan kesehatan melalui ata mbeko dengan jenis penyakit yang sama, yaitu gangguan jiwa dapat mendorong orang lain untuk memilih dan melakukan perawatan kesehatan ke ata mbeko. Hal serupa juga berlaku dalam pemilihan perawatan kesehatan secara medis. Terutama apabila pengalaman orang lain dalam melakukan perawatan kesehatan ke ata mbeko maupun medis menunjukkan gejala kesembuhan. Pada tahun 2020 Fitriani dan Eriyanti menuturkan bahwa setiap masyarakat ataupun pasien yang melakukan pengobatan biasanya mendapatkan informasi tentang pengobatan 
tersebut dari tetangga, teman atau orang-orang sekitarnya. Biasanya jika pengobatan itu membawa perubahan lebih baik atau membawa dampak yang baik terhadap pasien, maka akan menjadi acuan dalam pengambilan keputusan perawatan kesehatan.

\section{c. Biaya}

Kondisi keuangan keluarga ODGJ menjadi salah satu pertimbangan dalam menentukan sistem perawatan kesehatan. Masyarakat yang kurang mampu secara ekonomi tidak jarang mengabaikan masalah kesehatan karena biaya yang mahal. Hal ini didukung dengan pernyataan SL (keluarga pasien) berikut ini. (Minggu, 7 Maret 2021):

“... Biaya perawatannya cukup besar. Saya sebagai anak sulung dalam keluarga jadi tulang punggung di keluarga ini. Saya masih harus selesaikan kuliah dari dua orang adik saya. Saya dengan terpaksa menghentikan perawatannya karena saya tidak mampu untuk biayai ine dan biayai kuliah dua orang adik saya secara bersamaan. Apalagi selama rawat di Renceng Mose kami bayar pakai uang sendiri karena tidak ada tanggungan BPJS. Beda sekali waktu dulu pergi ke ata mbeko, saya tidak terlalu pikirkan uangnya karena bisa dibilang murah dan bisa dijangkau. Nanti kalau kedua adik saya selesai kuliah, akan tetap lanjutkan perawatannya di Renceng Mose. Untuk sekarang kami masih lanjutkan berobat dengan dukun karena memang untuk situasi sekarang ini hanya mampu di situ. Nanti baru lanjut lagi ke Renceng Mose".

Tingkat keuangan menentukan akses pada pelayanan kesehatan. Masyarakat yang kaya dapat memilih pelayanan kesehatan sekehendaknya mulai dari perawatan, fasilitas pelayanan, dan jenis obat-obatannya. Sebaliknya masyarakat dengan basis sosial ekonomi rendah akan kesulitan mengakses pelayanan kesehatan yang maksimal (Widianto, 2016). Selain itu, aspek geografis seperti jarak, lama perjalanan, jenis transportasi dan infrastruktur jalan juga membuat biaya kesehatan semakin mahal. Hal ini dituturkan oleh FM (keluarga pasien) sebagai berikut. (Rabu, 24 Februari 2021):

“... Waktu pertama kali saya bawa dia ke Renceng Mose. Saya sewa mobil pick upnya orang. Di sini mungkin kau tahu kalau biaya sewa mobil mahal. Apalagi medan jalannya kita yang di Manggarai ini cukup sulit. Belum lama di jalannya hampir 4 jam memang. Sewa mobil mahal, belum sewa sopirnya, uang rokok, uang bensin atau solarnya dan juga uang makan. Kalau saya hitung-hitung hampir dua juta. Itupun sampai di sana waktu itu dia belum langsung masuk ke panti. Setelah saya datang kedua kalinya baru dia bisa masuk panti untuk mulai direhab. Hampir tiga juta lebih uang untuk transpor dan makannya kami yang pergi antar dia”.

Masyarakat Manggarai memilih pengobatan dukun karena biayanya yang relatif murah. Biasanya para dukun tidak memberikan patokan harga khusus bagi pasien yang dirawatnya, tetapi tergantung keikhlasan dan kesanggupan keluarga pasien. 


\section{d. Persepsi tentang Keberadaan Fasilitas Pelayanan Kesehatan}

Fasilitas pelayanan kesehatan adalah suatu alat dan/atau tempat yang digunakan untuk menyelenggarakan upaya pelayanan kesehatan, baik promotif, preventif, kuratif, maupun rehabilittatif yang dilakukan oleh pemerintah, pemerintah daerah, dan/atau masyarakat (Peraturan Pemerintah Nomor 47 Tahun 2016 Tentang Fasilitas Pelayanan Kesehatan). Persepsi masyarakat Manggarai mengenai keberadaan fasilitas pelayanan kesehatan, yakni kesehatan jiwa dapat mempengaruhi dijelaskan oleh MAS (keluarga pasien) sebagai berikut. (Kamis, 11 Februari 2021):

“....Kami sudah lama tahu kalau di sini ada tempat khusus untuk rawat orang yang sakit seperti anak saya ini makanya kami segera bawa dia ke sana. Apalagi tempatnya dekat dari kami. Kami sudah lama tahu Renceng Mose".

Selain itu, FW (keluarga ODGJ) juga menjelaskan persepsinya mengenai fasilitas pelayanan kesehatan sebagai berikut. (Selasa, 9 Maret 2021):

“...Ada tetangga saya yang bekerja sebagai aparat desa. Dia sudah banyak dengar informasi tentang penyakit yang dialami saudari saya. Dia beritahu tentang Renceng Mose. Saya sendiri awalnya tidak tahu tempat situ. Selain itu, saya juga dapat info dari kegiatan sosialisasi yang dilakukan oleh puskesmas di desa ini. Orang yang kerja di puskesmas sarankan saya untuk bawa saudari saya ke Renceng Mose. Akhirnya waktu itu dia dibawa ke sana".

SL (keluarga ODGJ) menyampaikan tentang persepsi tentang fasilitas pelayanan kesehatan berikut ini. (Minggu, 7 Maret 2021):

“... ine sudah sakit selama sembilan tahun. Selama tujuh tahun dia tidak pernah kami bawa untuk periksa secara medis. Kami hanya pergi ke dukun dan kasi dia minum ramuan tradisional. Kami sudah anggap dia gila. Saya tidak pernah tahu ada yang namanya tempat rehabilitasi untuk orang gila. Apalagi di Manggarai ini saya tidak tahu tentang tempat seperti itu. Masuk tahun ke delapan baru ada orang yang beri tahu ke saya tentang Panti Rehabilitasi Renceng Mose. Setelah saya tahu baru saya bawa dia ke Renceng Mose. Saya akui kalau saya lambat tahu info tentang Renceng Mose. Seandainya sejak awal saya tahu tentang Renceng Mose pasti sudah sejak lama saya bawa dia ke sana dan dia tidak akan sakit hingga bertahuntahun begini".

Dari penuturan MAS, FW, dan SL menunjukan bahwa persepsi masyarakat Manggarai mengenai keberadaan fasilitas kesehatan Renceng Mose dipengaruhi oleh jarak fasilitas kesehatan dengan lingkungan atau tempat tinggal masyarakat Manggarai. Masyarakat yang tinggal dekat dengan Renceng Mose dapat dengan mudah membawa anggota keluarganya yang mengalami gangguan jiwa ke Renceng Mose. Para tenaga kesehatan di puskesmas dan aparatur berperan penting dalam memberikan informasi mengenai keberadaan Renceng 
Mose kepada masyarakat Manggarai. Ketidaktahuan masyarakat Manggarai mengenai keberadaan fasilitas kesehatan Renceng Mose menyebabkan terhambatnya perawatan kesehatan ODGJ secara cepat dan tepat.

\section{e. Keparahan Penyakit}

Ditinjau dari teori model kepercayaan kesehatan, semakin parah gejala gangguan jiwa yang dialami ODGJ, maka semakin cepat pula tindakan dalam melakukan sistem perawatan kesehatan. Sebaliknya, jika gejala gangguan jiwa yang ditimbulkan tidak menunjukkan gejala yang dianggap membahayakan, maka kemungkinan melakukan perawatan kesehatan sangat kecil atau bahkan tidak ada. Hal ini didukung oleh pernyataan FM (Keluarga ODGJ) berikut ini. (Rabu, 24 Februari 2021):

“... Dulu dia bekerja sebagai toor guide. Lalu, berhenti kerja dan mulai berhalusinasi bahwa ada yang benci dan mau mencelakakan dia. Seminggu setelah itu, seseorang memintanya untuk menjadi mc acara kampanye. Empat hari setelah menjadi mc kampanye dia kesurupan. Saya pikir awalnya kesurupan biasa tapi waktu diobati tidak sembuh. Saya pikir jangan-jangan anak saya ini kena usus turun karena tanda-tandanya memang terlihat seperti orang yang punya penyakit usus turun. Lalu, saya bawa dia ke dokter untuk diperiksa dan ternyata tidak menunjukkan gejala usus turun. Selain itu, tidak puas dengan dokter saya bawa lagi dia ke orang yang bisa periksa dan tahu obati penyakit usus turun. Saya coba ke pengobatan tradisional. Setelah diperiksa ternyata hasilnya juga sama bahwa anak saya ini tidak mengalami usus turun. Saya juga bawa dia ke dokter bagian dalam untuk diperiksa dan hasil pemeriksaanyapun tetap sama. Anak saya memang tidak kena penyakit usus turun. Setelah satu bulan baru saya sadar bahwa anak saya memang bukan kerasukan tetapi benar-benar sakit. Karena kondisinya yang semakin parah kami bawa dia ke Renceng Mose".

Dari penuturan FM (keluarga ODGJ) di atas menunjukan bahwa keluarga selalu berusaha melakukan penanganan dan pengobatan terhadap ODGJ. Pada mulanya gejala gangguan jiwa dipahami sebagai kesurupan. Hal ini sesuai dengan pandangan personalistik. Sejalan dengan adanya teori model kepercayaan kesehatan, secara subjektif keluarga menilai gangguan jiwa sebagai penyakit usus turun. Atas dasar hal tersebut, keluarga membawa anggota keluarga yang mengalami sakit ke dokter maupun pengobatan tradisional untuk diperiksa. Setelah hasil pemeriksaan tidak sesuai dengan dugaan keluarga, barulah mereka memahami bahwa penyakit yang dialami oleh anggota keluarganya adalah gangguan jiwa. 


\section{Implikasi Penanganan Rehabilitasi Bagi ODGJ dan Keluarganya a. Implikasi Penanganan Rehabilitasi terhadap ODGJ}

1) Implikasi Positif

Terjalinnya hubungan yang baik antara para tenaga kesehatan jiwa dan ODGJ dapat mempermudah kesembuhan. Hal ini didukung dengan pernyataan A (eks ODGJ) berikut ini. (Senin, 15 Februari 2021):

"Lakukan pasien seperti teman. Mereka sering ajak untuk cerita. Pasien dengan para petugas termasuk mereka bruder sangat akrab. Jadinya selama di sana saya rasa nyaman. Saya rasa suasana yang seperti itu sangat membantu saya untuk sembuh. Beberapa bulan setelah pulang rehabilitasi dari Renceng Mose saya lamar kerja. Puji Tuhan saya diterima. Sampai sekarang saya masih kerja di puskesmas dan sejauh ini tidak ada gejala gangguan jiwa lagi seperti yang saya alami sebelumnya".

Dari penuturan A (eks ODGJ) di atas dapat dikatakan bahwa penanganan rehabilitasi dapat memampukan ODGJ untuk menjalankan perannya sesuai dengan status yang dimilikinya ketika kembali ke lingkungan masyarakat. ODGJ yang sembuh setelah menjalani rehabilitasi dapat diterima dengan baik keberadaanya di masyarakat, khususnya di dunia kerja. Lingkungan tempat kerja turut memberikan kepercayaan kepada eks ODGJ untuk dapat menjalankan perannya secara optimal.

Penanganan rehabilitasi terhadap ODGJ juga merupakan suatu kesempatan dalam pemenuhan gizi yang diperlukan oleh tubuh. Hal ini diungkapkan oleh D (ODGJ) berikut ini. (Selasa, 9 Maret 2021):

“...Saya senang tinggal di sini karena makanannya enak. Tiap hari makanannya beda-beda. Terus makanannya bergizi lagi. Dan pasti makan tiga kali sehari. Kalau di rumah belum tentu saya bisa makan enak seperti di sini".

Penanganan rehabilitasi memimalisir terjadinya tindakan kekerasan yang mungkin dilakukan oleh ODGJ terhadap orang lain. Selain itu, rehabilitasi menjadi suatu wadah dalam menjalin relasi terhadap sesama. Hal ini didukung dengan pernyataan LJ (eks ODGJ) di bawah ini. (Senin, 8 Februari 2021):

'...Dulu saya jarang bergaul. Tapi, selama direhabilitasi saya punya banyak teman. Saya senang berada di panti karena saya dikontrol dengan baik. Jadinya tidak ada hal-hal membahayakan yang bisa saya lakukan. Saya lebih tenang".

Rehabilitasi tidak hanya melibatkan ODGJ dan tenaga kesehatan. Dukungan keluarga merupakan salah satu faktor penting bagi kesembuhan ODGJ yang sedang menjalani rehabilitasi. Selama menjalani proses rehabilitasi dukungan keluarga dapat diimplementasikan dalam bentuk adanya kunjungan terhadap ODGJ selama berada di panti. A (eks ODGJ) 
mengungkapkan bentuk dukungan keluarga sebagai berikut. (Senin, 15 Februari 2021):

“...Keluarga, bapa dan mama sering sekali jenguk selama saya direhabilitasi. Biasanya dua kali dalam seminggu. Punya keluarga yang pengertian dan mendukung saya membuat saya lebih cepat sembuh. Kalau saja tidak ada mereka mungkin penyakit yang saya alami akan lebih parah lagi. Untungnya dulu mereka cepat bawa saya ke Renceng Mose."

\section{2) Implikasi Negatif}

Penanganan rehabilitasi belum menjamin bahwa ODGJ yang telah sembuh setelah menjalani rehabilitasi bebas dari stigma. Stigma yang melekat dalam diri eks ODGJ menyebabkab adanya rasa kurang percaya diri. Hal ini diungkapkan oleh A (eks ODGJ) sebagai berikut. (Senin, 15 Februari 2021):

“...Kadang saya merasa tidak percaya diri kalau ada orang yang tahu saya pernah alami gangguan jiwa. Di tempat kerja teman-teman merasa was-was kalau gejala gangguan jiwa yang pernah saya alami akan kambuh lagi. Meraka juga was-was jangan sampai saya salah kasi obat ke pasien. Orang-orang di sekitar saya memperlakukan saya seperti orang normal pada umumnya. Tetapi, saya tidak tahu apakah mereka mengatakan yang buruk tentang saya ketika tidak sedang bersama saya."

Stigma terhadap eks ODGJ juga dijelaskan oleh FM (keluarga pasien) sebagai berikut (Rabu, 24 Februari 2021):

"...Setelah direhabilitasi di Renceng Mose dia sembuh lalu dibawa pulang, tetapi kambuh lagi. Kami tidak tahu pasti penyebabnya, entah dia mendapat perlakuan buruk atau karena hal lainnya. Kami juga tidak mau berprasangka bahwa dia kambuh lagi karena diperlakukan dengan buruk, diejek atau mungkin dihina selama dia bekerja lagi."

Stanislaus Mujur (pegawai Renceng Mose) juga menjelaskan tentang stigma yang dialami oleh eks ODGJ. Berikut ini adalah penuturannya. (Jumat, 12 Maret 2021):

“...Memang ada ODGJ yang setelah kembali ke keluarga dan masyarakat diterima dengan baik tanpa adanya pandangan negatif terhadap dirinya. Namun, ada juga ODGJ yang diterima dengan baik tetapi kadang kala dianggap sebagai orang gila. Contohnya adalah keluarga saya yang bernama (D). Setelah selesai direhabilitasi dan kembali ke masyarakat dia diterima dengan baik. Masyarakat di kampung sering bergaul dengan dia. Namun, saking asiknya ganda mereka secara sadar atau tidak bilang bahwa D orang gila. Jadinya (D) kambuh lagi dan direhabilitasi di sini lagi."

Stigma dapat menyebabkan kambuhnya gejala gangguan jiwa yang pernah dialami oleh eks ODGJ dan bahkan gejalanya bisa saja lebih parah 
dari sebelumnya. Tidaklah mengherankan bahwa tidak lama setelah keluar dari Renceng mose, Keluarga membawa mereka ke sana lagi untuk direhabilitasi.

\section{b. Implikasi Penanganan Rehabilitasi terhadap keluarga}

\section{1) Implikasi Positif}

Menurut (Sulastri, 2018) mengungkapkan bahwa tingkat ketergantungan pasien terhadap pemenuhan kebutuhan dasarnya pada keluarga cukup tinggi. Hal ini tentunya akan mengganggu pelaksanaan tugas dan tanggung jawab anggota keluarga dalam menjalankan fungsinya masingmasing. Apabila keluarga dipandang sebagai suatu sistem, maka akan terganggulah pencapaian tujuan keluarga. Pasien dianggap sebagai beban keluarga yang dapat mempengaruhi sistem dalam keluarga secara keseluruhan. Hal ini ditunjukkan dengan pernyataan MA (keluarga pasien) di bawah ini. (Rabu, 3 Maret 2021):

“...Mama sering minta pulang, tetapi kami tidak mau dia pulang karena kami lihat kondisinya belum terlalu baik. Jadi, biar saja mama di sana karena lebih diperhatikan. Kami sibuk kerja dari pagi sampai sore, kasihan kalau mama dengan kami karena tidak ada yang jaga. Kerjanya kami juga jadi terganggu kalau kami yang urus dia."

Dari penuturan MA dapat diketahui bahwa ODGJ merupakan suatu beban bagi keluarga dari segi waktu. Keluarga masing-masing sibuk bekerja dan tidak memiliki waktu untuk merawat atau mengurusi ODGJ. Sibuk bekerja membuat keluarga menjadi kurang memperhatikan ODGJ. Menempatkan ODGJ di Panti Renceng Mose merupakan solusi dalam menanganani ODGJ karena tidak menyita waktu kerja keluarga.

\section{2) Implikasi Negatif}

Banyak kasus ODGJ merasa lebih nyaman dan jauh lebih sehat jiwanya dalam waktu yang cukup lama saat berada di rumah sakit, tetapi lebih cepat kambuh kembali ketika ODGJ tersebut dikembalikan ke keluarga. Hal ini terjadi karena kurang teredukasinya keluarga secara baik sehingga gagal menjalankan perannya untuk menciptakan lingkungan yang kondusif dan bersifat terapeutik bagi kesembuhan ODGJ (https://rs-erba-go.id/beritaerba/pentingnya-peran-keluarga-dalam-penyembuhan-penderita-gangguan jiwa-odgj). Hal ini didukung dengan penjelasan FW (keluarga pasien) berikut ini. (Selasa, 9 Maret 2021)

"...Kondisinya sangat aman dan baik waktu dia keluar dari Renceng Mose. Tapi, beberapa bulan setelah itu kambuh lagi. Mungkin karena obatnya sudah habis. Ditambah lagi dengan kakak iparnya yang sering bicara yang bikin dia tersinggung. Jadinya kambuh lagi”. 
Keluarga ODGJ juga mendapat stigma dari masyarakat. Hal ini menyebabkan kesalahan perawatan kesehatan ODGJ. Hal ini didukung oleh pernyataan FM (Keluarga ODGJ) berikut ini.

(Rabu, 24 Februari 2021).

"...Setelah direhabilitasi di Renceng Mose dia sembuh lalu dibawa pulang, tetapi kambuh lagi. Untuk sekarang kami ikat kakinya. Kami ikat karena dia jalan telanjang tanpa pakaian."

Keluarga putus asa dalam menghadapi ODGJ yang kambuh lagi setelah direhabilitasi. Hal ini didukung oleh pernyataan FM (Keluarga ODGJ) berikut ini. (Rabu, 24 Februari 2021):

“....Kami frustasi dan cape rawat anak ini. Sudah sembuh tapi malah kambuh lagi. Kami tetap beri dia obat walaupun kami sebenarnya sudah pasrah bahkan kalau Tuhan mau ambil dia sekarang. Tengah malam jam tiga dia berteriak-teriak yang membuat kenyamanan tetangga atau orang sekitar sini menjadi terganggu. Kadang adiknya merasa jengkel karena suara ribut yang dibuatnya. Namun, saya selalu berusaha untuk memberikan pengertian ke adiknya bahwa bisa saja ini adalah takdir dari Tuhan."

Rasa putus asa yang dialami keluarga tidak berarti bahwa keluarga tidak melakukan pengobatan. Keluarga tetap melakukan pengobatan semampunya. Keputusasaan yang dialami oleh keluarga didukung dengan adanya upaya reseliensi. Upaya reseliensi keluarga ditunjukkan dengan adanya sikap pasrah pada Tuhan dan menganggap bahwa gangguan jiwa merupakan takdir.

\section{Kesimpulan}

Berdasarkan pembahasan di atas dapat disimpulkan bahwa: Pertama, Persepsi orang Manggarai terhadap etiologi gangguan jiwa secara naturalistik adalah gangguan jiwa disebabkan karena adanya gangguan biologis pada tubuh manusia dan tekanan dalam memenuhi kebutuhan hidup. Secara psikososio budaya, masyarakat Manggarai masih menganggap ODGJ sebagai aib dan keluarga mendapatkan stigma, sehingga pemasungan terhadap ODGJ tidak dapat dihindari. Orang Manggarai juga menganggap bahwa gangguan jiwa disebabkan karena kerasukan setan atau roh, kesalahan dalam melakukan ritual adat, dan karma dari leluhur. Kedua, Proses dan mekanisme pengambilan keputusan sistem perawatan kesehatan ODGJ dipengaruhi oleh beberapa faktor yang meliputi pengetahuan dan kepercayaan mengenai gangguan jiwa, pengalaman orang lain, biaya, persepsi tentang keberadaan fasilitas pelayanan kesehatan, dan keparahan penyakit. Ketiga, Implikasi penanganan rehabilitasi terhadap ODGJ dan keluarganya dapat dilihat secara positf dan negatif. Secara positif, implikasi penanganan rehabilitasi terhadap ODGJ, yaitu terjalinnya hubungan baik antara ODGJ dan tenaga kesehatan, memampukan ODGJ untuk menjalankan perannya sesuai dengan status yang dimilikinya ketika kembali ke lingkungan masyarakat, memimalisir terjadinya tindakan kekerasan yang mungkin dilakukan oleh ODGJ terhadap orang lain. 
Selain itu, rehabilitasi menjadi suatu wadah dalam menjalin relasi terhadap sesama serta adanya dukungan keluarga. Implikasi negatifnya, yaitu bahwa ODGJ masih mendapat stigma bahkan setelah sembuh dari rehabilitasi. Implikasi positif penanganan rehabilitasi bagi keluarga adalah dapat meringankan beban keluarga ODGJ. Adapun implikasi negatifnya adalah keluarga ODGJ juga mendapat stigma darimasyarakat, sehingga ODGJ yang kambuh setelah menjalani rehabilitasi masih ada yang dipasung. Di sisi lain adanya sikap pasrah dan putus asa keluarga ODGJ dalam balutan reseliensi. 


\section{BIBLIOGRAFI}

Danandjaja, James. (1994). Antropologi psikologi: teori, metode dan sejarah perkembangannya.Google Scholar

Fitriani dan Eriyanti, F. (2020). Relasi Pengetahuan dan Kekuasaan Dukun dalam Pengobatan tradisional Pada Masyarakat Dusun Lubuk Tenam Kecamatan Jujuhan Ilir Kabupaten Jungo Provinsi Jambi. Jurnal Riset Tindakan Indonesia, 5(1), 30. Google Scholar

Foster dan Anderson, B. (2015). Antropologi Kesehatan. Jakarta: Penerbit Universitas Indonesia (UI-Press).

Herdiyanti dan Cholila, J. (2017). Pergeseran Modal Sosial Dalam Pelaksanaan Upacara Adat Mandi Belimau di Dusun Limbung Desa Jadah Bahrin Kecamatan Merawang Kabupaten Bangka. Jurnal Society, 5(2), 2. Google Scholar

Herdiyanto, Yohanes. (2017). Stigma Terhadap Orang Dengan Gangguan Jiwa di Bali. Inquiry Jurnal Ilmiah Psikologi, 8(2), 128. Google Scholar

Kasniyah, Naniek. (1985). Etiologi Penyakit secara Tradisional dalam Alam Pikiran Orang Jawa: Celaka, Sakit, Obat, dan Sehat Menurut Konsepsi Orang Jawa. Proyek Penelitian Dan Pengkajian Kebudayaan Nusantara (Javanologi). Direktorat Jenderal Kebudayaan Depdikbud. Google Scholar

Koentjaranigrat. (1992). Beberapa Pokok Antropologi Sosial. Jakarta: Dian Rakyat.

Nasriati, Ririn. (2020). Stigma dan Dukungan Keluarga Dalam Merawat Orang Dengan Gngguan Jiwa. Jurnal Medisains Ilmu-Ilmu Kesehatan, 15 (1), 60. Google Scholar

Peraturan Pemerintah Nomor 47 Tahun 2016. (2016). Fasilitas Pelayanan Kesehatan. Google Scholar

Putro, Bambang Dharwiyanto. (2019). Riak Gelombang Resiliensi Keluarga Orang Dengan Gangguan Jiwa (ODGJ) Dalam Balutan Aspek Budaya Bali. Pustaka, XIX (2), 94, 100. Google Scholar

Riskesdas. (2018). Badan Penelitian dan Pengembangan Kesehatan RI. Google Scholar

Riyanto dan Budiman. (2013). Kapita Salekta Kuesioner Pengetahuian dan Sikap Dalam Penelitian Kesehatan. Jakarta: Salemba Medika. Google Scholar

Sarwono, Solita. (1993). Sosiologi kesehatan: beberapa konsep beserta aplikasinya. Gadjah Mada University Press. Google Scholar

Simanjuntak, Julianto. (2013). Konseling gangguan jiwa \& okultisme. Gramedia Pustaka Utama. Google Scholar 
Siswanto, Siswanto. (2007). Kesehatan Mental: Konsep, Cakupan, dan Perkembangannya. Yogyakarta: Andi Offset. Google Scholar

Soemarjono. (1998). Proses dan Mekanisme Pelayanan Unit Rehabilitasi Rumah Sakit Jiwa Pusat Lawang Sebagai Upaya Resosialisasi Pasien Gangguan Jiwa. Skripsi Universitas Udayana.

Suci, Intan, S,M. (2018). Analisis Hubungan Faktor Individu dan Beban Kerja Mental Dengan Stres Kerja. The Indonesian Journal of Occupational Safety and Health, 7 (2), 225. Google Scholar

Sugiyono. (2017). Metode Penelitian Kualitatif Untuk Penelitian yang Bersifat: Eksploratif, Enterpretif, Interaktif dan Konstruktif. Bandung: Alfabeta. Google Scholar

Sulastri, Sulastri. (2018). Kemampuan Keluarga dalam Merawat Orang dengan Gangguan Jiwa. Jurnal Kesehatan, 9(1), 131-137. Google Scholar

Suyono, Aryono. (1985). Kamus Antropologi. Jakarta: PT Akademi Presindo. Google Scholar

Tjana, Kadek Ayu C. S. (2020). Strategi Koping Keluarga Pasien Etnis Bali Terhadap Pasien Orang Dengan Ganggguan Jiwa (Studi Anrtopologi Psikologi di Rumah Sakit Jiwa Provinsi Bali, Bangli. Skripsi. Universitas Udayana.

Undang-Undang Nomor 18 tahun 2014. (2014). Kesehatan Jiwa.

Widianto, Ahmad Arif. (2016). Menjembatani Aksesibilitas Masyarakat Miskin pada Pelayanan Kesehatan Melalui Institusi Lokal. Jurnal Sosiologi Reflektif, 8(1), 4974. Google Scholar

\section{Copyright holder:}

Isabela Dibyacitta Adelian, Ida Bagus Gde Pujaastawa, I Gusti Putu Sudiarna (2021)

First publication right:

Syntax Idea

\section{This article is licensed under:}

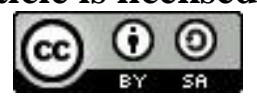

